\title{
Empire's Children: Child Emigration, Welfare, and the Decline of the British World, 1869-1967
}

Review Number: 1663

Publish date: Thursday, 2 October, 2014

Author: Ellen Boucher

ISBN: 9781107041387

Date of Publication: 2014

Price: $£ 60.00$

Pages: 301pp.

Publisher: Cambridge University Press

Publisher url: http://www.cambridge.org/gb/academic/subjects/history/british-history-after-1450/empires-childrenemigration-welfare-and-decline-british-world-18691967

Place of Publication: Cambridge

Reviewer: Christopher Bischof

Empire's Children is far from the now well-worn tale of imperial decline. It locates the shifting fortunes of the child emigration movement at the heart of the reconfiguration of identities, political economies, and nationalisms in Britain, Canada, Australia, and Rhodesia. Though Britons eventually had to face the diminishing importance of Britishness as either a cultural or racial ideal in the eyes of even their settler colonies, on the whole the story of the child emigration movement's shifting fortunes testifies to the malleability and resilience of Britishness.

As agitation for independence ramped up in much of the empire in the early 20th century, the concept of 'Greater Britain,' as late-Victorian historian J. R. Seeley famously called the settler colonies he thought would overtake India as the linchpin of the empire, took on a greater importance. During the inter-war years, the idea of a Greater Britain bound together by a shared culture and racial identity reached its peak. This idea rose to popularity at a time when, not coincidentally, charity organizations in Britain were struggling to provide for hundreds of thousands of orphaned and poor children while the settler colonies were hungry for white Britons to settle their vast hinterlands. For a one-time outlay of $£ 10$, a charity organization like Barnardo's could pay for a child's emigration and save itself $£ 16$ per year in maintenance costs while the colonies gained future white citizen-farmers (p. 43-4). The reimagining of the British Empire complemented the imperatives of imperial political economy.

By the 1920s and 1930s, however, the dominions - as the settler colonies were known from 1907 onward had begun to push back against an unchecked flow of child emigrants. No longer confident that these children had all the qualities they wanted simply by virtue of being British, dominion authorities began to screen their mental health and regulate the curriculum of the philanthropic institutions that received them in the dominions. For their part, British government officials and experts in child psychology lost confidence in the value of emigration for British children. Indeed, reports of the overwork and mistreatment of child emigrants frayed the bonds of trust that underpinned Greater Britain and the child emigration scheme. The regulation and eventual turn away from British child emigration was, then, bound up with the decline of Greater Britain. However, it was also part of generative processes that give rise to other identities. The turn 
away from British child emigration was a key site for the articulation of Canadian, Australian, and Rhodesian national identity as well as for a new definition of Britishness located in a welfare state that, among other things, prided itself on keeping families together whenever possible.

The book begins by charting the constellation of reconceptualizations that underpinned the rise of the child emigration movement. Pauperism was recast as the byproduct of capitalism rather than as a personal failing. This made it possible to imagine pauper children growing up to be productive citizens in spaces where the competition for land and work were not so intense. Emigration, long seen as a sign of failure, came to be regarded as 'a respectable life decision,' or even an adventure because of 'booster literature' touting the success of emigrants and the stories told by the nearly one-third of mid- and late-Victorian emigrants who eventually returned to Britain (p. 28). Related, the settler empire came to seem to be a source of 'boundless imperial fertility' rather than an unknown, potentially worthless land (p. 30). Finally, the 'kith and kin' connections of the settler empire became more meaningful and seemed stronger to Britons as unrest and even agitation for independence troubled other parts of the empire. Together, these late-Victorian cultural transformations made it possible 'to define needy children as essential imperial assets, the bedrock of Greater Britain, and the cornerstone of the worldwide Britannic race' (p. 55).

The main body of the book focuses on the child emigrant movement itself. Early on, Canada was the main focus for child emigration schemes. Not only was it comparatively close to Britain and hungry for children especially boys - to help out on farms, but the Canadian government subsidized the movement at the rate of $\$ 1,000$ to a charity for the first one hundred children it resettled per year and $\$ 500$ for each additional hundred. However, Canada was also the site of the earliest backlash against the child emigration. A "popular nationalism' arose in Canada that contrasted 'the qualities of "home grown" Canadians with the supposed defects of more recent arrivals' (p. 83). The well-publicized suicides of two allegedly overworked child emigrants in the winter of 1923 led the British government to appoint the Bondsfield Commission to investigate child emigration to Canada. The commission found that children placed in Canadian households were being used 'primarily for working purposes' and consequently losing out on an education which they would otherwise have gotten in Britain even as poor, institutionalized children (p. 87). It recommended a ban on the resettlement of young children who had not yet finished their schooling as part of an effort "to uphold a pan-imperial understanding of child welfare' (p. 88). Moreover, during their investigations in Canada the commissioners encountered popular agitation seeking assurance that, as one Canadian put it, 'the British government was not dumping its undesirables in Canada' (p. 86). Though both the British and the Canadian governments felt pressure to better regulate or end child emigration, the final decision to ban it came from the Canadian government and took effect on 1 April 1925.

Once Canada was no longer an option, charities doubled down on their projects in other dominions, especially Southern Rhodesia and Australia. Charities favored sending child emigrants to institutions in these countries rather than boarding them out with families as they had in Canada. In part this was to avoid the abusive overwork of children. Even more important, however, was the role institutions played in socializing children into the economic and racial roles that their new countries scripted for them. The Fairbridge Farm School, located in Pinjarra on the southwestern coast of Australia, features perhaps most prominently of the institutions examined. Kingsley Fairbridge, its eponymous founder, was born in South Africa and raised in Rhodesia, but educated in Oxford on a Rhodes scholarship. His own thinking about the empire owed much to Cecil Rhodes. He framed his work at Pinjarra not in terms of a religious crusade or a project of social justice, but as the product of his 'deep devotion to the cause of imperialism' (p. 64). The outpouring of support to the tune of tens of thousands of pounds on his first fundraising tour testified to how well that devotion resonated with donor organizations such as the Red Cross, the Rhodes Trust, and the National Relief Fund. At Pinjarra the children learned to be farmers, a curriculum demanded by an Australian government that feared its cities were becoming overburdened while its farmland was underpopulated. The government made its continued support of the Fairbridge school contingent on the centrality of agriculture to the curriculum. The school also taught local geography and literature. The making of Australians took place on a more everyday level as well, such as learning to walk around without boots or socks - a practice which required a painful period of adjustment for children's soft British soles. At the 
Rhodesia Fairbridge Memorial College, the curriculum was designed to cultivate a 'characteristically Rhodesian' community, though the most important lessons of all - the nature of the racial order - were implicitly woven into everyday life (p. 221).

The end of child emigration owed in part to pushback from the dominions, which began to impose health, IQ, and respectability requirements. However, it also owed to the growing purchase of the idea that even a poor, broken family was better for a child than being institutionalized. John Bowlby played a key role in popularizing this idea with his 1953 Child Care and the Growth of Love, which claimed that children who did not get intimate affection from a mother or mother-figure suffered from 'maternal deprivation', which had crippling effects on their intellectual and social development (p. 183). With the rise of Bowlbyism, child emigration no longer seemed like either an ethical option or one that would benefit the dominions.

Fittingly, Empire's Children has a peripatetic narrative. It frequently flits between Britain and the dominions, one dominion and another. Though this approach can sometimes make for a slightly jarring read, it goes a long way towards making good on the potential of transnational history to tell a story that is at once coherent and comparative, unified in some ways and attentive to parochial differences in others. The narrative also moves between many different perspectives, including those of child migrants and their parents, child experts, British and dominion government officials, and the leaders of charitable organizations and institutions. Almost every chapter opens with an anecdote from one of the 41 oral histories that Boucher conducted with child emigrants. At times this felt disingenuous given the focus of most chapters on government officials and voluntary sector leaders, but these glimpses of the 'dislocation', 'excitement', and 'pride' experienced by child emigrants helps to connect the high-level, often abstract debates about race, imperial political economy, and national identity to the everyday experiences of the children whose lives were so profoundly shaped by them.

The final chapter makes good on the full promise of this multi-layered approach to the history of child emigrants by giving a richly textured sense of their experiences and the worldviews to which they gave birth. For the parents of child emigrants, talking about the reasons they gave their consent was difficult. Even though Geoff Crimes, who emigrated to Rhodesia in 1952, did not resent his mother for her decision to acquiesce to the charity officials' request that he emigrate, he found 'feelings of guilt and loss' haunted her such that she could not even discuss it (p. 201-2). Like many parents of child emigrants, however, she was a single parent coping with poverty dire enough to lead her to place her child in a charitable institution in the first place. Many children saw emigration as an adventure and eagerly volunteered for it. The actual experience could be quite different, however. For Michael Snell, who emigrated to Australia in 1950, the excitement of the journey itself gave way to feelings of 'boredom and resentment' at the obsessive focus on agriculture in the curriculum at his Australian school (p. 211). The propagandistic films of famous Australian agriculturalists and the long hours spent in the fields rather than the classroom led him 'to define himself less as a schoolchild than as a worker' (p. 212). Although Australia was becoming a more industrial nation, the powerful hold which tropes such as 'the determined sheep farmer' and 'the faithful farmwife' had on the national imagination preserved agriculture's prominent place in the curriculum for child emigrants, who needed to learn to be Australian as well as to contribute to the national economy (p. 216). In Rhodesia, by contrast, child emigrants were given a broader education because the culture there 'defined unskilled manual work as demeaning to Europeans' (p. 220). Oral histories with child emigrants to Rhodesia suggest that they were socialized into not only racism, but a racist paranoia. One recalled being warned that 'if we didn't look smart and, you know, get our education, [the Africans] would take our jobs'. Clearly each dominion's project to shape its economy and national culture deeply informed the experiences of child emigrants.

For all its groundbreaking work, Empire's Children could make clearer its intervention in three ongoing scholarly conversations. First, the exploration of the relationship between subjectivity and broader social, cultural, and political phenomenon along the lines of James Hinton's reading of mass observation diaries.(1) Despite the excellent use of oral history to shed light on child emigrants' experiences, it is not quite clear how they understood the relationship between those experiences and the larger projects of empire and nation 
building. Did they comprehend the utopian hopes which reformers and government officials vested in them as agents of economic growth and cultural stability? What, if any, sense of being part of 'something bigger' did they have and how did that shape their worldview and identity? The second conversation is about the nature of Britain. Though Boucher acknowledges from the outset that individuals could 'imagine themselves as members of multiple and overlapping communities', 'British' becomes an overarching identity that subsumes rather coexists with Englishness, Welshness, and Scottishness. Given the strong sense of Scottish identity and culture in Canada and Australia from earlier waves of emigration, did child emigrants from Scotland meet with a warmer welcome than their English counterparts? Were Welsh parents more resistant to the entire scheme owing to the Anglican influence on many of the charities and institutions involved? Did the idea of child migration and farm schooling have its roots in Victorian Scotland's preference for a boarding out system of child welfare centered on farm work and its resistance to Poor Law and charitable institutions after the English model? Finally, Empire's Children could build on the work of Jordanna Bailkin and others by making clearer how the decline of the empire - in this case, child emigration - shaped postwar British society.(2) For instance, one child emigrant to Rhodesia who eventually returned to London in the 1960s recalled that she 'slammed her lunch tray down on the table and walked out' of a cafe when a black man sat next to her (p. 254). Boucher reads this incident as evidence of the difficulty return migrants had adapting to the comparative diversity and multiculturalism of post-war Britain. However, for me it raises the question of the extent to which return migrants created and sustained those racial tensions which very much continued to exist in post-war Britain. I also wonder to what extent the dominions' push back against child emigration provided the impetus for British child experts, charitable institutions, and the welfare state to develop new welfare practices and the new ideas about childhood known as Bowlbyism.

Empire's Children is ambitious, but it delivers with wide-ranging research and powerful analysis that firmly establish the importance of child emigration to modern British history. It connects topics that have often been treated separately: childhood and imperialism, identity and political economy, British welfare and the dominions. The child emigration movement and the backlash against it were central to the 20th-century reconfiguration of Britishness in the wake of a changing imperial order.

\section{Notes}

1. James Hinton, Nine Wartime Lives: Mass Observation and the Making of the Modern Self Nine Wartime Lives (Oxford, 2010). Back to (1)

2. Jordanna Bailkin, The Afterlife of Empire (Berkeley, CA, 2012). Back to (2)

The author is happy to accept this review and does not wish to comment further.

Source URL:https://reviews.history.ac.uk/review/1663

\section{Links}

[1] https://reviews.history.ac.uk/item/107399 